\title{
LYN Gene Mutation
}

National Cancer Institute

\section{Source}

National Cancer Institute. LYN Gene Mutation. NCI Thesaurus. Code C133690.

A change in the nucleotide sequence of the LYN gene. 